\title{
Sulfur K-edge XANES Spectroscopy as a Tool for Understanding Sulfur Dynamics in Soil Organic Matter
}

\author{
Dawit Solomon,* Johannes Lehmann, and Carmen Enid Martínez
}

\begin{abstract}
Sulfur K-edge X-ray absorption spectroscopy (XANES) was used to identify $S$ oxidation states and assess the impact of land use changes on the amount, form, and distribution of organic $S$ in particle-size separates and their humic substance extracts. Soil samples $(0-10 \mathrm{~cm})$ were collected from natural forest, tea plantations, and cultivated fields at Wushwush and from natural forest, Cupressus plantations and cultivated fields at Munesa sites in Ethiopia. Sulfur XANES spectra measured directly from the size separates could not be quantitatively analyzed due to high background noise. However, qualitative comparison of spectra from size separates and their humic extracts were very similar and thus provides a characteristic fingerprint of $S$ in mineral soils. $X$-ray absorption near-edge spectroscopy showed the presence of most reduced (sulfides, disulfides, thiols, and thiophenes), intermediate (sulfoxides and sulfonates) and highly oxidized S (ester$\mathrm{SO}_{4}-\mathrm{S}$ ) forms. Sulfur in intermediate oxidation states was dominant $(39-50 \%$; where $66-96 \%$ of it being sulfonate $S)$ in humic extracts from clay, while highly oxidized $S$ dominated $(40-56 \%)$ the silt spectra. Concentrations of $\mathrm{C}$-bonded and ester-SO $\mathrm{S}_{4}-\mathrm{S}$ extracted by the $\mathrm{HI}$ fractionation did not correlate with those from XANES (ester-SO ${ }_{4}-\mathrm{S}$ revealed by XANES vs. HI-fractionation, $r=0.23 ; P<0.001)$. A major shift following land use changes occurred in the most reduced and intermediate $S$ species. Their proportion decreased in the order: natural forests $>$ plantations $>$ cultivated fields. In contrast, highly oxidized $\mathbf{S}$ increased in the order: natural forests $<$ plantations $<$ cultivated fields at both sites. Our results indicated that $\mathrm{C}$-bonded $\mathrm{S}$ (most reduced and intermediate $\mathrm{S}$ ) may represent the more labile forms of organic $\mathrm{S}$ compounds compared with ester-SO $\mathrm{S}_{4}-\mathrm{S}$. Therefore, $S$ K-edge XANES has a significant potential to evaluate the influence of anthropogenic changes on the nature and distribution of $S$ and to follow its dynamics in terrestrial ecosystems.
\end{abstract}

$\mathrm{S}^{\mathrm{v}}$ ULFU IS A highly reactive element, existing in several oxidation states and moving freely among the lithosphere, hydrosphere, and atmosphere. The accumulation and cycling of $\mathrm{S}$ are central to many biological processes and provide a key to understanding changes in the biosphere. Sulfur cycling also significantly influences atmospheric and oceanic chemistry and the global energy balance. Therefore, the chemistry of S compounds in the environment has taken on a new significance in recent years because human activities have dramatically altered the biogeochemical S cycling in terrestrial ecosystems.

The soil environment is the primary component of the global biogeochemical $\mathrm{S}$ cycle, acting as a source and sink for various $\mathrm{S}$ species and mediating changes

D. Solomon and J. Lehmann, Dep. of Crop and Soil Sciences, Cornell Univ., Bradfield and Emerson Hall, Ithaca, NY 14853; C.E. Martínez, Dep. of Crop and Soil Sciences, 418 ASI Building, The Pennsylvania State Univ., University Park, PA 16802. Received 18 Nov. 2002. *Corresponding author(ds278@cornell.edu).

Published in Soil Sci. Soc. Am. J. 67:1721-1731 (2003).

(C) Soil Science Society of America

677 S. Segoe Rd., Madison, WI 53711 USA in oxidation states. Sulfur occurs in soil both in organic and inorganic forms. However, most of the soil $\mathrm{S}$ $(>95 \%)$ in temperate and tropical ecosystems is present in organic forms (Janzen and Ellert, 1998; Saggar et al., 1998; Solomon et al., 2001a). Knowledge of the speciation of $\mathrm{S}$ in organic materials could, therefore, provide a clearer understanding of the amount, form, and biogeochemical transformations of $\mathrm{S}$ in the ecosystem. Our knowledge of the biogeochemical S cycling is, however, severely limited by relatively crude analytical techniques used in $\mathrm{S}$ measurements and speciation. Most of the present studies on soil organic $\mathrm{S}$ are based on a fractionation technique using $\mathrm{HI}$ reduction of organic S compounds in soil (Tabatabai, 1982; Kowalenko, 1993a,b). The biochemical characterization of organic $\mathrm{S}$ as ester- $\mathrm{SO}_{4}-\mathrm{S}$ (HI-reducible $\mathrm{S}$ ) and $\mathrm{C}$-bonded $\mathrm{S}$ has advanced the understanding of the organic $S$ cycle in soil (e.g., McGill and Cole, 1981; Janzen and Ellert, 1998; Lehmann et al., 2001; Solomon et al., 2001a). However, this technique is only an indirect method involving differential reduction of organic $\mathrm{S}$ compounds to $\mathrm{H}_{2} \mathrm{~S}$ and is, therefore, not an entirely satisfactory procedure to directly speciate $\mathrm{S}$ within complex organic functional groups. Moreover, this chemical reduction method cannot identify intermediate oxidation states of $\mathrm{S}$ in organic matter and consequently almost no information is available about their turnover rates. Other studies have attempted to speciate $\mathrm{S}$ into its functional groups using pyrolysis gas chromatography mass spectrometry in aquatic humic substances (Van Loon et al., 1993) and kerogens (Carmo et al., 1997) for characterization of $\mathrm{S}$ containing moieties, but this approach is limited to speciation of thermally stable forms of $\mathrm{S}$ (Hundal et al., 2000).

Synchrotron-based S K-edge XANES spectroscopy has been successfully used to speciate and quantify all oxidation states of $\mathrm{S}$ in a variety of geochemical samples ranging from petroleum (Waldo et al., 1991a,b), coal (Huffman et al., 1995), marine sediments (Vairavamurthy et al., 1993, 1994), biosolids (Hundal et al., 2000) to soil humic and fulvic acids (Morra et al., 1997; Xia et al., 1998; Szulczewski et al., 2001). X-ray absorption near-edge structure spectroscopy has also proven to be a valuable tool in the identification and quantification of $\mathrm{S}$ oxidation states in organic soils (Martínez et al., 2002). Sulfur XANES spectroscopy is a solid-state technique that circumvents the limitations of chemical reduction methods and provides a means to directly determine the various $\mathrm{S}$ species based on the energy required

Abbreviations: CEC, cation-exchange capacity; eV, electron volt; PIPS, passivated implanted planar silicon detector; R-S/O-S, ratios of most reduced $\mathrm{S}$ to highly oxidized $\mathrm{S} ; \mathrm{I}-\mathrm{S} / \mathrm{O}-\mathrm{S}$, ratios of intermediate S to highly oxidized S; SOC, soil organic C; SOM, soil organic matter; XANES, X-ray absorption near-edge structure spectroscopy. 
for core electron transitions to bound states or ejection into continuum. The proportions of $\mathrm{S}$ in each oxidation state could be influenced by soil degradation and may reflect labile and stable S pools. However, up to now the influence of land use changes on $\mathrm{S}$ oxidation states of soils could not be determined. Therefore, there is a need to conduct comparative studies that involve land use changes, which may help to describe important reactions of $\mathrm{S}$ to long-term management changes. This technique can be combined with physical fractionation of soil according to particle-size separates, which has been demonstrated to provide ecologically meaningful soil S pools (Solomon et al., 2001a). Thus, S K-edge XANES spectroscopy may offer a significant potential to evaluate the influence of anthropogenic changes on the nature and distribution of $\mathrm{S}$ and follow its dynamics in terrestrial ecosystems.

The objectives of this study were, therefore, to assess the potential of S K-edge XANES spectroscopy to characterize the impact of deforestation and subsequent land use changes on the amount, form, and distribution of $\mathrm{S}$ fractions in size separates of soils. The results from XANES spectroscopy were related to previous results of wet-chemical $\mathrm{S}$ fractionation from clay and silt separates (Solomon et al., 2001a) of the soils under investigation.

\section{MATERIALS AND METHODS}

\section{Site Description}

The present research was conducted at the southwestern highlands (Wushwush) and the southeastern Rift Valley escarpment (Munesa) of Ethiopia. Wushwush is located at $7^{\circ} 19^{\prime}$ $\mathrm{N}$ lat. and $36^{\circ} 07^{\prime} \mathrm{E}$ long. The altitude of the area is $1900 \mathrm{~m}$ above sea level. Mean annual temperature is $18^{\circ} \mathrm{C}$ with an average annual precipitation of $1800 \mathrm{~mm}$. The soils of the area consist of well-drained surface soil where layers between 60 and $75 \mathrm{~cm}$ exhibit the presence of plinthite and redoximorphic features. They have clayey texture, dark reddish brown color and are classified as Plinthaquic Paleudalfs (Soil Survey Staff, 1999). The Wushwush natural forest is mainly composed of Olea africana (Mill.), Syzygium guineense (Guill. Ex Perr.), Cordia africana (Lam.), Croton macrostachys (Hochst. ex Rich.), and Ficus vasta (Forssk.) The Munesa site is located at $7^{\circ} 35^{\prime} \mathrm{N}$ lat. and $38^{\circ} 45^{\prime} \mathrm{E}$ long. Mean annual temperature is $19^{\circ} \mathrm{C}$ with annual precipitation of $1250 \mathrm{~mm}$. The escarpment at Munesa extends from 2100 to $3200 \mathrm{~m}$ and the plain descends gradually to the Rift Valley lakes at $1600 \mathrm{~m}$ above sea level. The soils at Munesa are well-drained, clayey texture and have very dark reddish brown color. They are classified as Typic Palehumults (Soil Survey Staff, 1999). The natural vegetation of the Munesa forest ranges from the Arundinaria alpina (Schun.), Hagenia abyssinica (J.F. Gmel.), Croton macrostachys (Hochst. ex Rich.), Podocarpus falcatus (Thunb. Mirb.), Olea hochstetteri (Baker.) dominated forest on the escarpment to Acacia woodlands composed of Acacia tortilis (Forsk ex Hayne), Acacia abyssinica (Hochst. ex Benth.), and Acacia seyal (Delile) in the semi-arid lowlands.

Extensive deforestation of native natural forests in Southern Ethiopian highlands and their subsequent conversion in to low-input crop land or plantations either for the production of tea or lumber has caused extensive soil degradation. In the present study, we investigated natural forest, tea plantations (Camellia sinensis O. Kuntz) (35 yr old) and fields cultivated for $25 \mathrm{yr}$ at the Wushwush site while at the Munesa site Podo- carpus dominated natural forest, Cupressus plantations $(\mathrm{Cu}$ pressus lusitanica Mill.) (25 yr old) and fields cultivated for $30 \mathrm{yr}$ were investigated. In the cultivated fields of both sites, maize (Zea mays L.) was grown without fertilizer inputs. However, during the intermittent dry periods, sorghum (Sorghum bicolor L. Moench) was grown at Munesa. The plowing depth both at the Wushwush and Munesa sites varies from 10 to 12 $\mathrm{cm}$. Crop residues that remain on the fields are normally collected and used as animal feed at both sites.

We selected three representative fields from each land use system. After considering the depth of cultivation to minimize differences, which may arise due to the dilution of SOM from mixing of the surface soil with the subsoil through cultivation, we used a core sampler ( $200 \mathrm{~cm}^{3}$ core volume) and collected nine subsamples in a radial sampling scheme (Wilding, 1985) from the upper $10 \mathrm{~cm}$ of each field. A composite sample was then prepared from the subsamples. The samples were airdried and sieved $(<2 \mathrm{~mm})$ before fractionation and chemical analysis.

\section{Physical Fractionation}

After removing visible root remnants, particle-size fractionation was done on $<2-\mathrm{mm}$ material using a probe type sonicator (Branson Sonifier W-450, Schwäbisch Gmünd, Germany) in a soil/water ratio of 1:5 (w/v). The detailed procedure of isolation of the different size separates is described elsewhere (Solomon et al., 2002a). Previous studies on the amount, form, and structures of organic C (Solomon et al., 2002a,c), P (Solomon et al., 2002b), and S (Solomon et al., 2001a) compounds on these samples indicated no evidence of organic matter redistribution following soil fractionation procedure used in the present study.

\section{Chemical Analysis}

Carbon, $\mathrm{N}$, and $\mathrm{S}$ contents of clay and silt size separates were analyzed by dry combustion with a $\mathrm{C} / \mathrm{H} / \mathrm{N} / \mathrm{S}$-analyzer (Elementar Vario EL; Elementar Analysensysteme GmbH, Hanau, Germany). The $\mathrm{pH}-\mathrm{H}_{2} \mathrm{O}$ and $\mathrm{pH}-\mathrm{KCl}$ were determined in 1:2.5 soil/water (w/v) suspension. Cation-exchange capacity (CEC) was determined with $1 \mathrm{MNH}_{4} \mathrm{OAc}(\mathrm{pH}=7.0)$ according to Avery and Bascomb (1974). Dithionite-citratebicarbonate-extractable $\mathrm{Al}$ and $\mathrm{Fe}\left(\mathrm{Al}_{\mathrm{d}}, \mathrm{Fe}_{\mathrm{d}}\right)$ as well as oxalateextractable $\mathrm{Al}$ and $\mathrm{Fe}\left(\mathrm{Al}_{\mathrm{o}}, \mathrm{Fe}_{\mathrm{o}}\right)$ were determined using atomic absorption spectrometer (Varian AAS-400; Varian Techtron, Victoria, Australia) as described by Mehra and Jackson (1960) and Blume and Schwertmann (1969). The analysis of S fractions (inorganic $\mathrm{SO}_{4}-\mathrm{S}$, ester- $\mathrm{SO}_{4}-\mathrm{S}$, and $\mathrm{C}$-bonded $\mathrm{S}$ ) in the clay and silt size separates was done by HI reduction of $\mathrm{SO}_{4}^{2-}$ to sulfide and subsequent determination of $\mathrm{S}$ as bismuth sulfide by spectroscopy (Kowalenko, 1993a,b). Selected soil physical and chemical characteristics are shown in Table 1.

\section{X-Ray Absorption Near-Edge Structure Spectroscopy}

The humic substances from clay- and silt-size separates were extracted three times with $0.1 M \mathrm{NaOH}$ and $0.4 M \mathrm{NaF}$ at a ratio of 1:5 (w/v) and the combined extracts were dialyzed (Spectra/Por Membrane, MWCO, 12 000-14 000 Da; Spectrum Laboratories, CA). Thus, the humic substances studied in the present experiment have higher molecular weight ( $>12$ 000-14 $000 \mathrm{Da})$. The extraction procedure of humic substances followed the outline of Schnitzer (1982), as modified by Sumann et al. (1998). The $0.1 M \mathrm{NaOH} / 0.4 M \mathrm{NaF}$ extracts, however, were filtered through a $0.2-\mu \mathrm{m}$ membrane filter (Gelman Supor; Pall Gelman Laboratory, MI) under pressure. This procedure was repeated using the same membrane filter, 
Table 1. Selected physical and chemical properties of surface soil horizons (0-10 cm) sampled from the subhumid highlands of Ethiopia.

\begin{tabular}{|c|c|c|c|c|c|c|c|c|c|c|c|c|c|}
\hline Land use & Sand & Silt & Clay & pH & SOC $\dagger$ & $\mathbf{N}$ & $\mathbf{C} / \mathbf{N}$ & $\mathbf{S}$ & CEC $\ddagger$ & $\mathbf{F e}_{d} \S$ & $\mathbf{F e}_{0}$ II & $\mathbf{A l}_{\mathrm{d}} \S$ & $\mathbf{A l}_{0} \mathrm{I}$ \\
\hline & \multicolumn{3}{|c|}{$\longrightarrow \mathrm{g} \mathrm{kg}^{-1} \longrightarrow$} & KCl & \multicolumn{3}{|c|}{$\longrightarrow \mathrm{g} \mathrm{kg}^{-1}$ soil $\longrightarrow$} & $\mathrm{mg} \mathrm{kg}^{-1}$ & cmol & \multicolumn{4}{|c|}{$\longrightarrow \mathrm{g} \mathrm{kg}^{-}$} \\
\hline & \multicolumn{13}{|c|}{ Wushwush } \\
\hline Natural forest & 103 & 327 & 570 & 5.5 & 82 & 7.7 & 10.8 & 1082 & 37.0 & 6.7 & 0.60 & 0.96 & 0.25 \\
\hline Tea plantation & 102 & 330 & 568 & 4.5 & 42 & 4.0 & 10.4 & 719 & 24.7 & 6.5 & 0.70 & 0.97 & 0.32 \\
\hline Cultivation & 70 & 337 & 593 & 4.7 & 38 & 3.7 & 10.2 & 635 & 26.4 & 5.8 & 0.83 & 0.77 & 0.30 \\
\hline \multicolumn{14}{|c|}{ Munesa } \\
\hline Natural forest & 130 & 347 & 523 & 6.8 & 98 & 7.9 & 12.6 & 1041 & 52.2 & 2.5 & 0.30 & 0.38 & 0.15 \\
\hline Cupressus plantation & 231 & 326 & 443 & 6.6 & 71 & 7.1 & 10.0 & 903 & 40.4 & 2.5 & 0.36 & 0.32 & 0.18 \\
\hline Cultivation & 229 & 285 & 486 & 4.5 & 38 & 3.3 & 11.8 & 520 & 26.5 & 3.4 & 0.71 & 0.40 & 0.21 \\
\hline
\end{tabular}

+ SOC, Soil organic C.

+ Cation-exchange capacity.

$\S \mathrm{Fe}_{\mathrm{d}}$ and $\mathrm{Al}_{\mathrm{d}}$, dithionite-citrate-bicarbonate extractable $\mathrm{Fe}$ and $\mathrm{Al}$.

II $\mathrm{Fe}_{\mathrm{o}}$ and $\mathrm{Al}_{0}$, oxalate-extractable $\mathrm{Fe}$ and $\mathrm{Al}$.

where the partial plugging of the filter helps remove fine clay, and finally the extracts were freeze-dried. The $\mathrm{NaOH} / \mathrm{NaF}$ method extracts from 45 to $56 \%$ SOM (Solomon et al., 2002a).

Solid-state characterization of S oxidation states in clay and silt size separates and their humic substance extracts were performed using S K-edge XANES spectroscopy at beamline X-19A, the National Synchrotron Light Source (NSLS), at Brookhaven National Laboratory. The measurements from the clay and silt separates and humic substance extracts were conducted under standard operating conditions, that is, after calibrating the X-ray energy to the K-edge of elemental S, the spectrum was assigned an energy value of $2472 \mathrm{eV}$ and scans ranging from $50 \mathrm{eV}$ below to $150 \mathrm{eV}$ above the absorption edge of $\mathrm{S}$ were collected with a step size of $0.2 \mathrm{eV}$. Each XANES spectrum was composed of an average of three scans. A monochromator consisting of double crystal Si (111) with an entrance slit of $0.5 \mathrm{~mm}$ and minimum energy resolution of $2 \times 10^{-4}(0.5 \mathrm{eV})$ at the S K-edge was used. The spectra were recorded in fluorescence mode using a passivated implanted planar silicon (PIPS) detector (Canberra Industries, CT). The beam path from incident ion chamber to the sample chamber was purged with $\mathrm{He}$ gas. The samples were pressed into thin films by using $0.5-\mathrm{mm}$ thick acrylic holder and covered with a 2.5- $\mu \mathrm{m}$ thick Mylar film (Complex Industries, NY).

The S K-edge data collection and analysis was done as described by Xia et al. (1998), Hundal et al. (2000), and Martinez et al. (2002). Deconvolution of XANES spectra for each sample into pseudocomponents was done using the nonlinear least squares fitting routine Solver supplied by MS-Excel (Microsoft Inc., Redmond, WA). The XANES spectra were fitted using a series of Gaussian peaks (G1, G2, G3, G4, and G5) that represent the $s \rightarrow p$ transitions (white line) and arctangent step functions (AT1 and AT2) that represent the transition of ejected photoelectrons to the continuum (step height or background). The energy positions (eV) of the Gaussian curves were used to identify the oxidation states of S present in the sample. The linear component of the spectral baseline was removed before fitting and the areas were corrected for the change in absorption cross-section with increasing oxidation state. The areas of the Gaussian curves were used to calculate the percentage of S present at that particular oxidation state. Because XANES reflects the distribution of electrons in the valence shell of $\mathrm{S}$ atoms in their actual bonding environment, the difference between electronic and formal oxidation states can be substantial, especially for reduced $\mathrm{S}$ species in complex organic materials, depending on whether $\mathrm{S}$ is bonded to S, H, C, or metals (Waldo et al., 1991a; Morra et al., 1997; Xia et al., 1998; Hundal et al., 2000). Due to the higher electronegativity of $\mathrm{O}$, the differences are not significant for higher-valence $(\geq+4) \mathrm{S}$ species and $\mathrm{S}$ atoms bound to multiple oxygen atoms. Therefore, in this study, we have reported the electronic oxidation states rather than formal oxidation states, as they reflect the actual electron density in the valence shell of S. Moreover, because of the above reasons, integer values were used to report the electronic oxidation states of the high-valence $\mathrm{S}$ species, while noninteger values were used for the low-valence $(\leq+4) \mathrm{S}$ compounds.

\section{Statistics}

Correlation coefficients showing the relationship between the different $\mathrm{S}$ compounds measured by HI reduction technique and S K-edge XANES spectroscopy were run by Pearson product moment correlation using the software package STATISTICA 5.0 for Windows (StatSoft. Inc., 1995).

\section{RESULTS AND DISCUSSION Speciation of Organic Sulfur Forms in Mineral soils}

Our previous study on these soils (Solomon et al., 2001a) indicated that organically bound $S$ is the major form of total S (98\%) and plays an important role in providing $\mathrm{S}$ for plant growth in these low-input subhumid tropical highland agroecosystems. Moreover, we have found that in the soils under investigation, most of the organic $\mathrm{C}, \mathrm{P}, \mathrm{S}$, and total $\mathrm{N}$ are present in clay and silt, and only minor amounts were found in sandsize separates. This makes the finer size separates of these tropical soils the major reservoirs of nutrients that occur as part of complex organic polymers (Solomon et al., 2001a; Solomon et al. 2002a,b). Therefore, S K-edge XANES spectra were recorded for the clay and silt size separates and for their humic substance extracts (Fig. 1 and 2).

According to Fig. 1, the experimental S XANES spectra measured directly from the clay and silt size separates show a large background, deflated signal, and an upward curving baseline compared with the spectra obtained from the humic substances extracted from the two size separates. These features make uniform data analysis (background correction and normalization of the data) from the direct measurements difficult using standard programs and were thus hindering reliable data analysis and quantitative comparison of the results. However, closer inspection of the selected regions (Fig. 2) shows that the main features of the spectra taken 


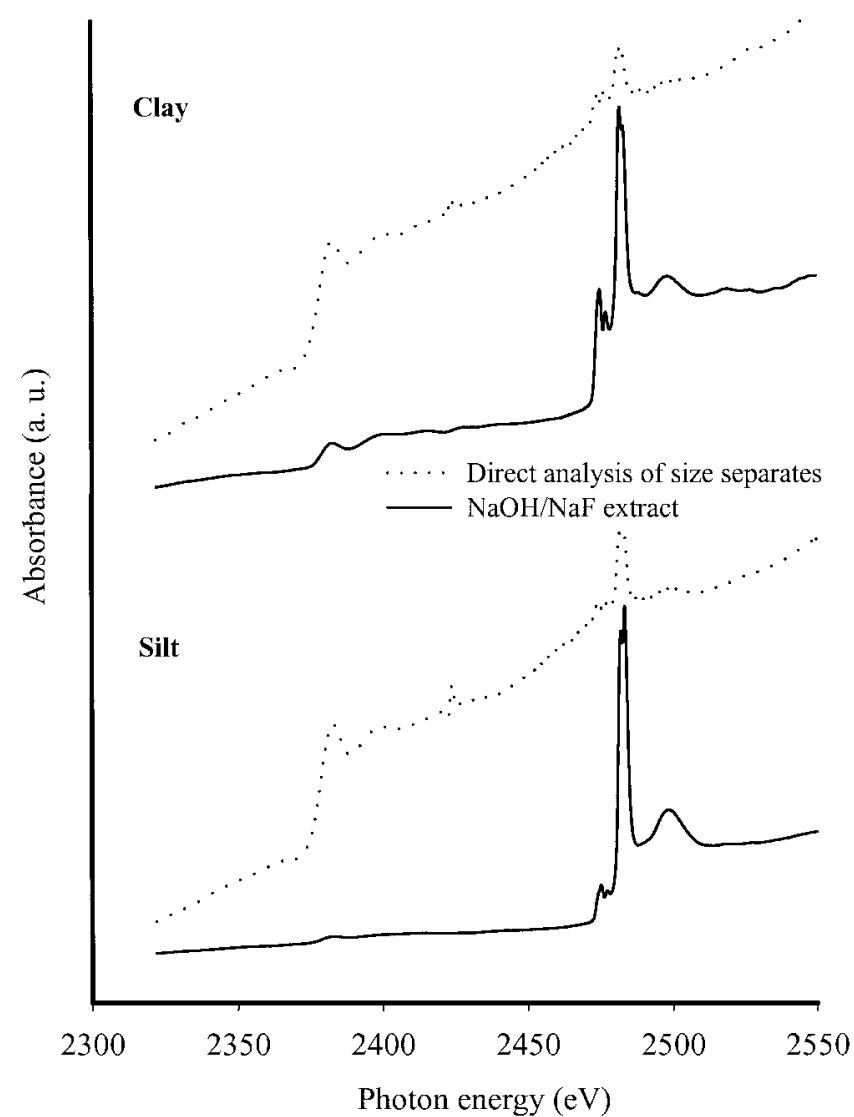

Fig. 1. Sulfur K-edge XANES spectra (before deconvolution and nonlinear least squares fitting) recorded directly from the clay (Wushwush) and silt (Munesa) size particles and humic substance extracts from these size separates.

directly from the clay and silt and their humic substance extracts are qualitatively very similar. According to Fig. 2, the spectra measured from the mineral soil particles and their humic substance extracts show the presence of four major absorption bands in the energy range of 2473 to 2476,2477 to 2478,2479 to 2483 , and 2483 to $2488 \mathrm{eV}$. These features were consistent throughout all S XANES spectra recorded. Therefore, it is possible to suggest that the S K-edge XANES spectra obtained from the extracts are representative of the XANES spectra recorded directly from the size separates and thus provide a characteristic fingerprint of entire organic $\mathrm{S}$ compounds in the clay and silt separates. Hence, this feature allows both qualitative and quantitative comparison of organic $\mathrm{S}$ species present at different oxidation states, which seems to be a promising way to obtain a deeper insight into the structural composition and turnover of organic $\mathrm{S}$ in mineral soils. The use of humic extracts for the subsequent analysis is also supported by the fact that they often represent up to of $75 \%$ of the total SOM (Schnitzer and Khan, 1972; Hutchison et al., 2001), that in most cases the chemical composition of organic $\mathrm{C}$ and $\mathrm{P}$ in mild $\mathrm{NaOH}$ extracts is representative of the total soil organic $\mathrm{C}$ and $\mathrm{P}$ (Fründ and Lüdemann 1989; Gressel et al., 1996; Möller et al., 2000, Solomon et al., 2002a,b), and that no detectable change have been found in the different oxidation states of $\mathrm{S}$

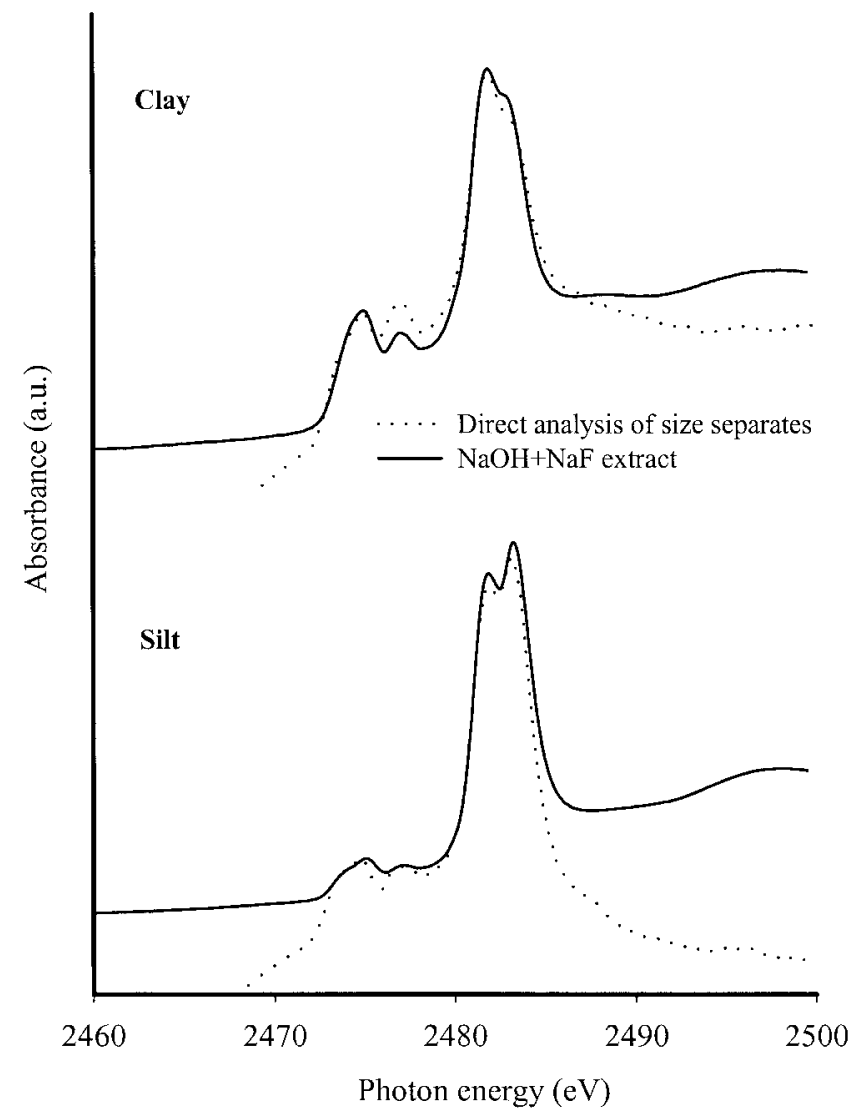

Fig. 2. Comparisons of selected regions of S K-edge XANES spectra from the clay (Wushwush) and silt (Munesa) size separate and $0.1 M \mathrm{NaOH} / 0.4 M \mathrm{NaF}$ extracts of these separates.

in samples exposed to aeration at various $\mathrm{pH}$ levels for up to $44 \mathrm{~h}$ (Hutchison et al., 2001).

In contrast to the XANES spectra taken directly from the size separates, the deconvoluted and fitted experimental spectra using a series of Gaussian curves and two arctangent step functions of the humic substance extracts resulted in a very good fit (Fig. 3). Therefore, all qualitative and quantitative comparisons and subsequent discussions in the present study are based on the results from the humic substance extracts.

Sulfur K-edge XANES spectroscopy is primarily used to determine the energy position of the white line resulting from the electron transition. It has been previously demonstrated that a linear relationship exists for $\mathrm{S}$ standards of known formal oxidation states and their respective white line position (Waldo et al., 1991a,b; Vairavamurthy et al., 1993, 1994; Morra et al., 1997). Although slight differences might exist between the formal and apparent oxidation states in the case of lower-valence organic S compounds, the unique spectral characteristics of the K-edge absorbance facilitate the identification of S compounds from XANES spectra (Morra et al., 1997). We present the base-line-corrected and normalized S K-edge XANES spectra in Fig. 4 and 5, and the relative energy position, predicted electronic oxidation states, and structure of representative S compounds in the humic substance extracts in Table 2. Accordingly, the XANES spectra in Fig. 4 and 5 show the presence of 


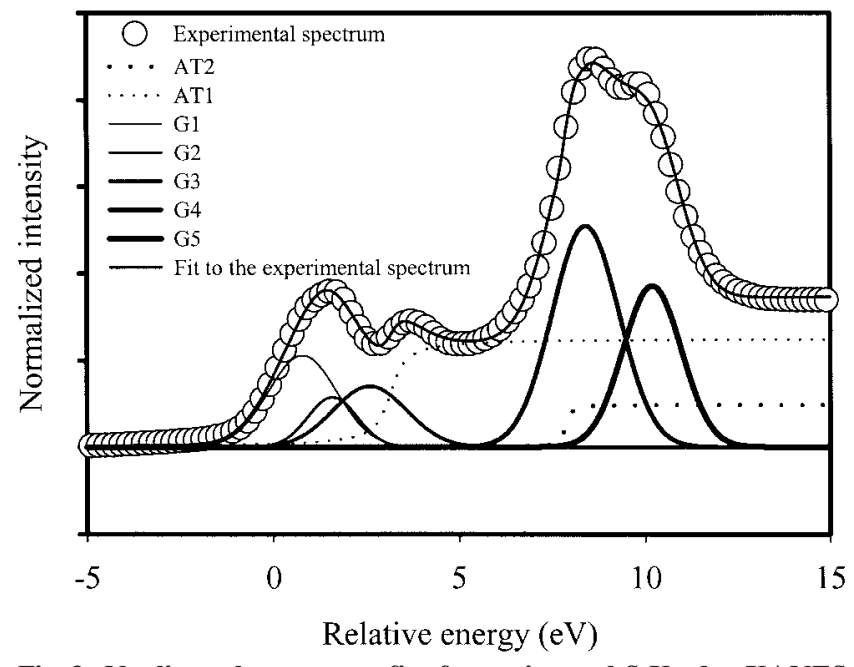

Fig. 3. Nonlinear least square fit of experimental S K-edge XANES spectrum showing several oxidation states of $\mathbf{S}$ analysis for humic substances extracted from clay size separates $(<2 \mu \mathrm{m})$ of a soil from Wushwush, Ethiopia. AT1 and AT2 are Arctangent 1 and 2. G1 to G5 are Gaussian Peak 1 to 5.

several white lines in the range of 0 to $10 \mathrm{eV}$ above the $\mathrm{S}$ K-edge energy, indicating the presence of multiple oxidation states of $\mathrm{S}$ in the humic substances. Based on data from literature (Morra et al., 1997; Xia et al., 1998; Martinez et al., 2002) and electronic oxidation states (Table 2) recorded in the present experiment, we grouped the different $\mathrm{S}$ oxidation states and $\mathrm{S}$ species associated with them into three major groups. These include: the most reduced (sum of G1 and G2, which include sulfides, disulfides, thiols, and thiophenes), intermediate (sum of G3 and G4, which include sulfoxides and sulfonates), and highly oxidized S (G5, representing sulfates) forms. Since the absorption cross-section increases approximately linearly with increasing oxidation state (Waldo et al., 1991a; Xia et al., 1998), the relative quantities of each $\mathrm{S}$ compound at the specific electronic oxidation states of the humic substances (Table 3 and 4) were estimated from the areas under each Gaussian curve after correcting for the change in absorption cross-section with oxidation state as shown in Fig. 3.

\section{Characteristics and Distributions of Organic S Compounds in Size Separates}

Organic S originates mainly from plant and animal residues, which are subsequently decomposed and remetabolized by soil microorganisms. Several early studies conducted on speciation of $\mathrm{S}$ involving differential reduction techniques indicate that ester- $\mathrm{SO}_{4}-\mathrm{S}$, where $\mathrm{S}$ is bonded to $\mathrm{O}$ in the form of $\mathrm{R}-\mathrm{OSO}_{3}-\mathrm{H}$ linkages, is the dominant form of organic $\mathrm{S}$ in soils and humic acid extracts, with a range of 33 to $93 \%$ reported for various soils and sampling depths by several authors (Fitzgerald, 1976; Houghton and Rose, 1976; Biederbeck, 1978). The remaining forms of organic $\mathrm{S}$ in soils include sulfonates $\left(\mathrm{R}-\mathrm{SO}_{3}-\mathrm{H}\right)$ and S-containing amino acids (R-S), in which $\mathrm{S}$ is directly bonded to $\mathrm{C}$. In contrast to these studies, Bettany et al. (1980), Lowe and Bustin (1989), and Möller et al. (2002) reported lower proportions (16-30\%) of ester- $\mathrm{SO}_{4}-\mathrm{S}$ in the humic extracts of a variety of temperate and tropical soils, suggesting that $\mathrm{S}$, which is directly bonded to $\mathrm{C}$ is the dominant form of organic $\mathrm{S}$ in soils. The white lines from the stacked S K-edge XANES spectra (Fig. 4 and 5) and the relative abundance of $S$ compounds at electronic oxidation states of the humic substances (Table 3 and 4) indicate that C-bonded organic $\mathrm{S}$ compounds found in the intermediate oxidation states are the dominant form of soil $\mathrm{S}$ in the humic substances extracted from clay separates of the studied subhumid tropical soils. They accounted for 39 to $50 \%$ of the organic $\mathrm{S}$ in the humic substances, where 66 to $96 \%$ of it was sulfonate S. These results are consistent with the XANES analysis of the high-valence $\mathrm{S}$ species in humic acids from soil, peat, and aquatic sediments by Morra et al. (1997), organic soils by Martinez et al. (2002), and partially consistent with the results of humic substances extracted from the organic horizon of soils by Xia et al. (1998). Morra et al. (1997) and Xia et al. (1998) have shown that humic acids produce white lines indicative of a high-valence $\mathrm{S}$ dominantly in the +5 oxidation state with smaller proportions of +6 state. Xia et al. (1998), however, reported that +6 oxidation state could be more dominant than +5 in some humic acids, while both oxidation states could be equivalent in others. The highly oxidized $\mathrm{S}$ compounds represented 15 to $44 \%$, while the most reduced $\mathrm{S}$ compounds in the form of sulfides, disulfides, thiols, and thiophenes comprised 17 to $38 \%$ of $\mathrm{S}$ in the humic substances extracted from clay.

Ester- $\mathrm{SO}_{4}-\mathrm{S}$ is predominantly generated through biochemical processes by the soil microflora, which metabolize organic residues; its abundance is controlled by the supply of S (Saggar et al., 1998). In contrast, C-bonded S (amino acid and sulfonate $\mathrm{S}$ ) is directly derived from leaf litter and root inputs, as well as microbial protein synthesis. Stevenson (1986) and Brady and Weil (1999) pointed out that the major form C-bonded $\mathrm{S}$ is mainly in the form of proteins and amino acids such as cysteine [HS- $\left.\mathrm{CH}_{2}-\mathrm{CH}\left(\mathrm{NH}_{2}\right)-\mathrm{COOH}\right]$, cystine [( $\mathrm{S}^{-} \mathrm{CH}_{2}-\mathrm{CH}\left(\mathrm{NH}_{2}\right)-$ $\left.\mathrm{COOH})_{2}\right]$, and methionine $\left[\mathrm{CH}_{3}-\mathrm{S}-\left(\mathrm{CH}_{2}\right)_{2}-\mathrm{CH}\left(\mathrm{NH}_{2}\right)-\right.$ $\mathrm{COOH}$. In contrast to current understanding (Stevenson, 1986; Brady and Weil, 1999), however, our S K-edge XANES spectra (Fig. 4 and 5) and the relative proportions of the different $\mathrm{S}$ compounds (Table 3 and 4) indicated that the humic substances extracted from clay are generally enriched with sulfonates. These results compare positively with the results of Stanko-Golden and Fitzgerald (1991), who demonstrated using a wetchemical degradation technique that sulfonates are the dominant components of the C-bonded S pool representing as much as $68 \%$ of the total S of forest-derived soils from Puerto Rico. Our results also indicate that the most reduced $\mathrm{S}$ compounds (sulfides, disulfides, thiols, and thiophenes) occur in larger amount in humic substances extracted from the clay than from the silt. This is also illustrated by the higher ratios of most reduced S to highly oxidized S (R-S/O-S) in the humic substances extracted from clay (0.40-2.2) than silt (0.200.44 ) and by the ratio of intermediate $S$ to oxidized $S$ (I-S/O-S), which lies between 0.89 to 3.3 in the clay and 

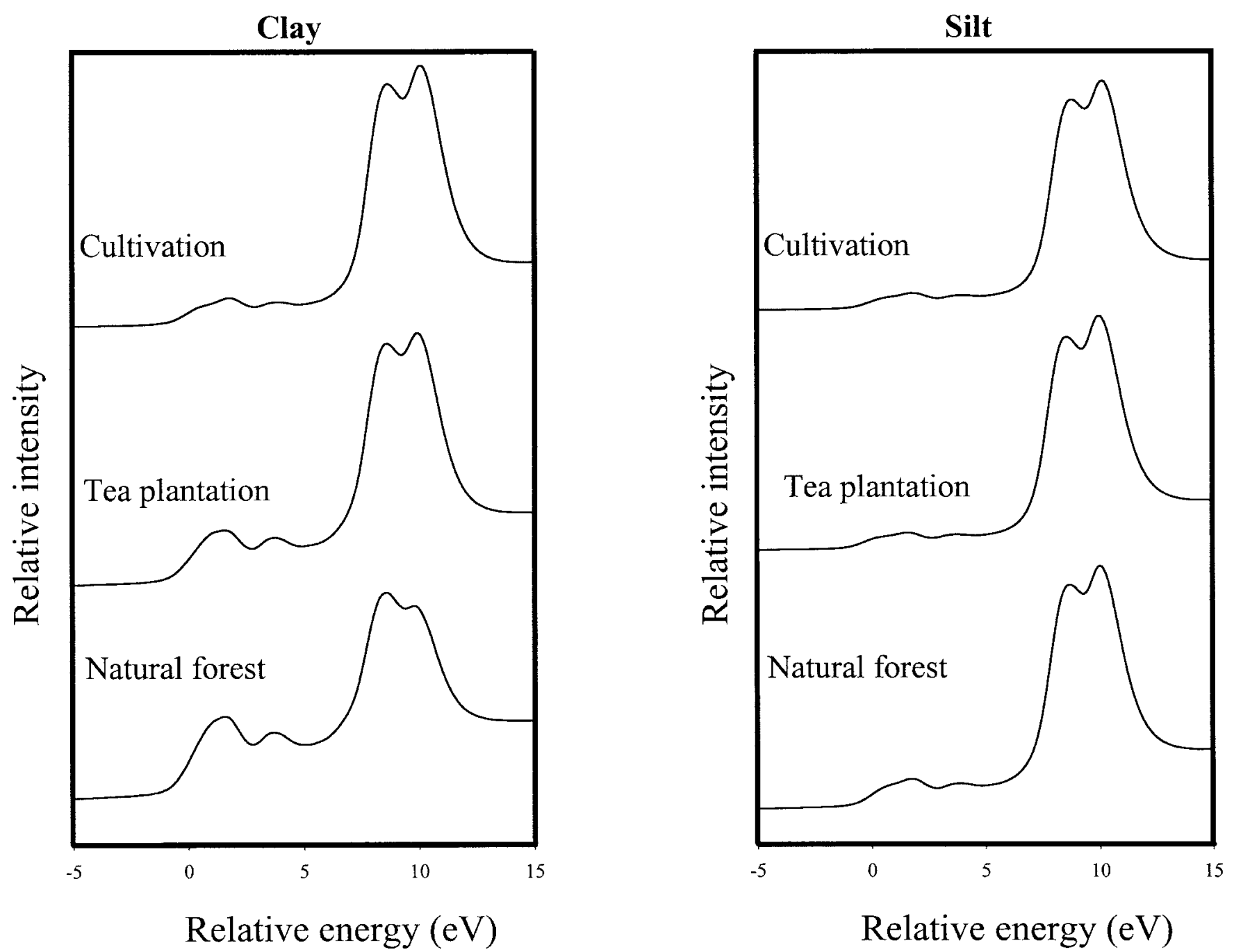

Fig. 4. Stacked S K-edge (2472 eV) XANES spectra for humic substances extracted from clay $(<2 \mu \mathrm{m})$ and silt size $(2-20 \mu \mathrm{m})$ separates of soils from Wushwush, Ethiopia.

0.59 to 1.1 in the silt size separates (Table 3 and 4 ). The results from the present experiment are supported by our previous studies on the composition of organic matter in the size separates of these (Solomon et al., 2002a) and other tropical soils (Solomon et al., 2000, 2001b), in which larger proportions of microbial metabolites such as carbohydrates (hexoses and deoxyhexoses) and amino sugars (hexoseamines and muramic acid) were found concentrated in clay than in silt. The higher prevalence of organic $\mathrm{S}$ at the intermediate and most reduced oxidation states in the humic substances extracted from the clay than from the silt may be attributed to physical and chemical stabilization of these products as a result of: (i) a higher association of $\mathrm{Fe}$ and $\mathrm{Al}$ oxides and hydroxides in clay, (ii) a higher reactivity and specific charge characteristics of clay minerals, and (iii) a higher active surface area that enhances the enrichment of these organic compounds in clay than in silt size separates.

Bettany et al. (1980) and Anderson et al. (1981) reported that clay separates are preferentially enriched in ester- $\mathrm{SO}_{4}-\mathrm{S}$. In contrast to the results of these research- ers and the patterns observed in the humic substances extracted from clay, the unique feature of S XANES spectra of the humic substances extracted from the silt (Fig. 4 and 5) is the presence of a large and distinctive white line in the positive high-valence region representing a highly oxidized S. According to Table 3 and 4, this highly oxidized $\mathrm{S}$ is the predominant form of $\mathrm{S}$ representing 40 to $56 \%$ of the total organic $\mathrm{S}$ in humic substance extracts from silt. Because inorganic $\mathrm{S}$ species are not present in significant proportions in the humic substances extracted from these soils (Solomon et al., 2001a), the large proportion of S found in the highly oxidized state is presumed to be ester- $\mathrm{SO}_{4}-\mathrm{S}$. Sulfur in the intermediate oxidation state accounted for 33 to $46 \%$, whereas the most reduced S oxidation states represented only 11 to $20 \%$ of total organic S in the humic substances extracted from silt. These results show that most reduced $\mathrm{S}$ compounds represent a small fraction of the total organic S pool in humic substances extracted from the silt size separates of these tropical soils. Moreover, we have also observed that the white lines of the S XANES spectra obtained from the humic substance 

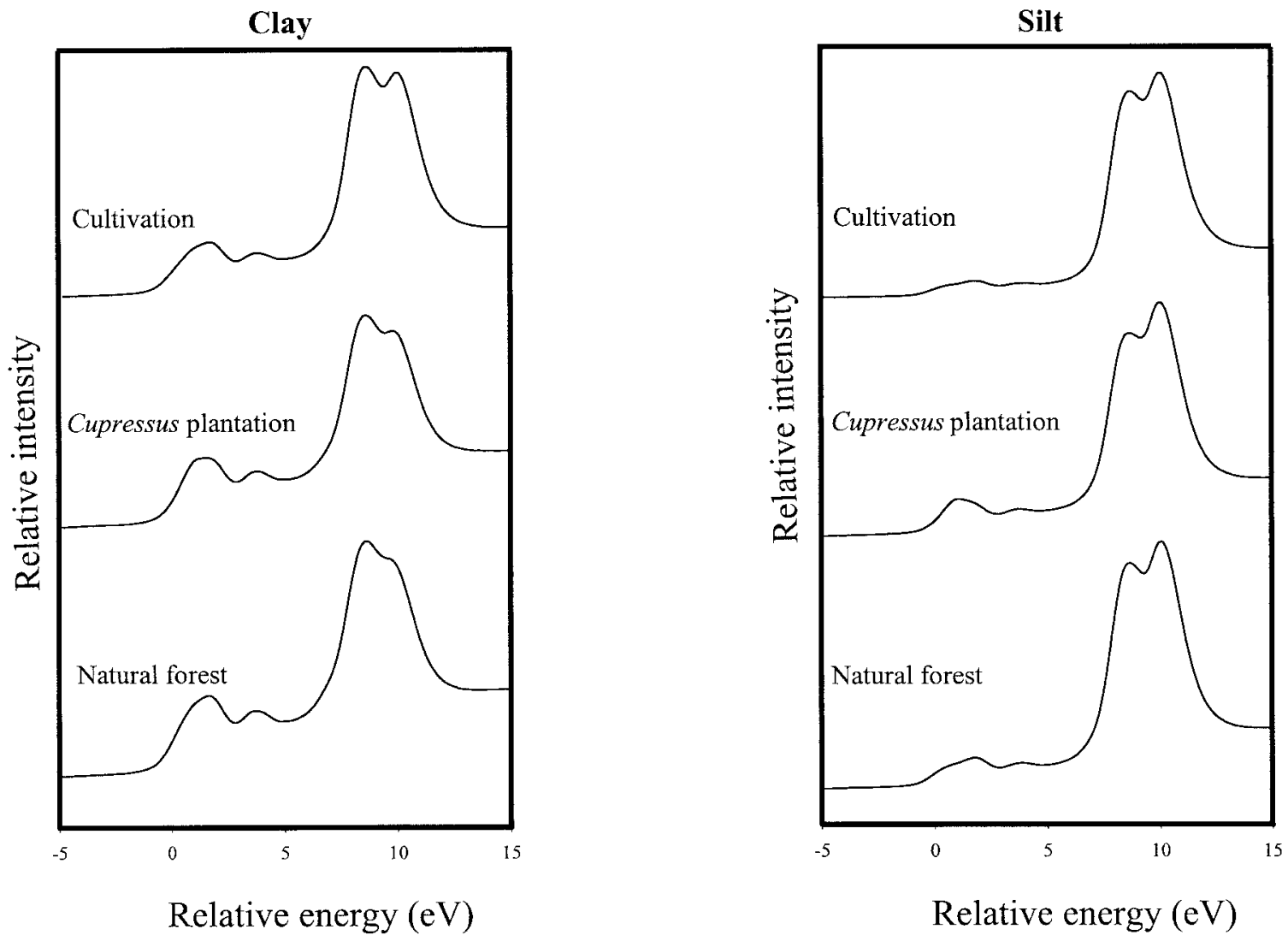

Fig. 5. Stacked S K-edge $(2472 \mathrm{eV})$ XANES spectra for humic substances extracted from clay ( $<2 \mu \mathrm{m})$ and silt size $(2-20 \mu \mathrm{m})$ separates of soils from Munesa, Ethiopia.

extracted from silt resemble more like the spectra recorded from fulvic than those of humic acids as reported by Morra et al. (1997).

\section{Comparison of Sulfur Speciation Obtained by Hydroiodic Acid Fractionation and XANES Spectroscopy}

In our previous study using the traditional wet chemical analysis technique, we have found that most of the organic S in the clay and silt size separates was present in C-bonded S (78-94\%), whereas ester- $\mathrm{SO}_{4}-\mathrm{S}$ constituted merely 6 to $22 \%$ of the organic S pool (Solomon et al., 2001a). These values were almost constant regardless of agricultural management and did not change much between the different size separates, despite the fact that total S decreased on the average by $46 \%$ on cultivation. With the help of S-XANES spectroscopy, however, we were able to successfully speciate, and quantify several S species according to their oxidation states. Moreover, the result of XANES spectroscopy demonstrated clear differences both in the pattern and proportion of organic S species between physically fractionated size separates, soils and land use making it a useful tool to assess $\mathrm{S}$ cycling in soil.

Hundal et al. (2000) showed that the relative proportions of reduced and oxidized $\mathrm{S}$ classes obtained from biosolid-derived fulvic acid agreed well with the estimates from HI-reducible S. We compared the relative abundance of the most reduced (G1 and G2), intermedi- ate (G3 and G4), and highly oxidized S (G5) as revealed by XANES to our earlier determinations of C-bonded and ester- $\mathrm{SO}_{4}-\mathrm{S}$ using wet chemical analyses (Solomon et al., 2001a). Unlike the results of Hundal et al. (2000), correlation coefficients showed a poor relationship (e.g., ester- $\mathrm{SO}_{4}-\mathrm{S}$ as revealed by XANES vs. HI-fractionation, $r=0.23 ; P<0.001$ ) between the compounds extracted using the two approaches. The widely differing values for the distribution of the $\mathrm{S}$ species reported in our previous (Solomon et al., 2001a) and current studies on these soils can be attributed to the procedures used to extract and quantify $\mathrm{S}$ species. In the previous study, we used a biochemical characterization of organic $\mathrm{S}$ as ester-SO $\mathrm{S}_{4}-\mathrm{S}$ (HI-reducible $\mathrm{S}$ ) and C-bonded S using an

Table 2. Relative energy position, predicted oxidation states and structures of representative organic $S$ compounds in the humic substance extracts of clay and silt size separates of tropical soils.

\begin{tabular}{|c|c|c|c|}
\hline $\begin{array}{l}\text { Sulfur } \\
\text { compound }\end{array}$ & $\begin{array}{c}\text { Energy } \\
\text { position }\end{array}$ & $\begin{array}{c}\text { Electronic } \\
\text { oxidation state }\end{array}$ & Structure \\
\hline \multicolumn{4}{|c|}{ eV } \\
\hline \multicolumn{4}{|c|}{ Most reduced $\mathbf{S}$} \\
\hline $\begin{array}{l}\text { Sulfide } \\
\text { Disulfide } \\
\text { Thiol } \\
\text { Thiophene }\end{array}$ & $0.76-1.8$ & $0.33-0.95$ & $\begin{array}{l}\text { R-S-R } \\
\text { R-S-S-R } \\
\text { R-S-H }\end{array}$ \\
\hline \multicolumn{4}{|c|}{$\underline{\text { Intermediate S }}$} \\
\hline $\begin{array}{l}\text { Sulfoxide } \\
\text { Sulfonate }\end{array}$ & $\begin{array}{l}1.9-2.5 \\
8.2-8.5\end{array}$ & $\begin{array}{c}1.3-1.8 \\
5.0\end{array}$ & $\begin{array}{l}\text { R-SO-R } \\
\text { R-SO } \\
\text {-H }\end{array}$ \\
\hline \multicolumn{4}{|c|}{ Highly oxidized S } \\
\hline Sulfate & $10.1-10 . \overline{2}$ & 6.0 & $\mathrm{R}-\mathrm{OSO}_{3}-\mathrm{H}$ \\
\hline
\end{tabular}


Table 3. Relative abundance of $S$ species at electronic oxidation states in humic substances extracted from clay $(<2 \mu \mathrm{m})$ and silt size (2-20 $\mathrm{mm})$ separates of studied soils at Wushwush, Ethiopia.

\begin{tabular}{|c|c|c|c|c|c|c|c|}
\hline \multirow[t]{2}{*}{ Land use } & \multicolumn{5}{|c|}{ Gaussian curve } & \multirow[t]{2}{*}{ R-S/O-S } & \multirow[t]{2}{*}{ I-S/O-S\$ } \\
\hline & $\begin{array}{c}\text { G1 } \\
(0.33-0.47) \dagger\end{array}$ & $\begin{array}{c}\text { G2 } \\
(0.71-0.95)\end{array}$ & $\begin{array}{c}\text { G3 } \\
(1.3-1.8)\end{array}$ & $\begin{array}{c}\text { G4 } \\
(5.0)\end{array}$ & $\begin{array}{c}\text { G5 } \\
(6.0)\end{array}$ & & \\
\hline & \multicolumn{5}{|c|}{ Clay } & & \\
\hline Natural forest & 27.9 & 9.7 & 15.5 & 30.0 & 16.9 & 2.2 & 2.7 \\
\hline Tea plantation & 19.4 & 6.3 & 9.5 & 31.0 & 33.8 & 0.76 & 1.2 \\
\hline \multirow{2}{*}{ Cultivation } & 12.4 & 4.9 & 2.0 & 37.0 & 43.7 & 0.40 & 0.89 \\
\hline & \multicolumn{5}{|c|}{$\underline{\text { Silt }}$} & & \\
\hline Natural forest & 10.8 & 3.6 & 9.2 & 36.4 & 40.0 & 0.36 & 1.1 \\
\hline Tea plantation & 6.5 & 4.4 & 1.5 & 40.4 & 47.2 & 0.23 & 0.89 \\
\hline Cultivation & 9.3 & 2.7 & 3.2 & 34.9 & 49.9 & 0.24 & 0.76 \\
\hline
\end{tabular}

+ Electronic oxidation states.

+ R-S/O-S, ratios of most reduced S (sum of G1 and G2, which include sulfides, disulfides, thiols and thiophenes) to highly oxidized S (G5, representing sulfates).

§ I-S/O-S, ratios of intermediate S (sum of G3 and G4, which include sulfoxides and sulfonates) to highly oxidized S (G5, representing sulfates).

indirect method involving differential reduction of organic $\mathrm{S}$ compounds to $\mathrm{H}_{2} \mathrm{~S}$. This procedure is not entirely effective to speciate $\mathrm{S}$ in complex organic functional groups compared with the direct and nondestructive technique used in the present study.

Based on the above results it is possible to suggest that, because of the sensitivity of XANES to the electron structure, oxidation state and geometry of the neighboring atom, S K-edge XANES spectroscopy coupled with physical fractionation provided a characteristic fingerprint information of the organic S compounds present in these tropical soils. These features could make $S$ K-edge XANES spectroscopy a valuable method to assess the long-term impact of anthropogenic changes on the nature and distribution of $\mathrm{S}$ and to follow its dynamics in terrestrial ecosystems. However, S K-edge XANES spectroscopy was not sensitive enough to differentiate the reduced S species such as sulfides, disulfides, and thiols. Sulfur L-edge XANES spectroscopy has been shown to provide complementary information to identify these $\mathrm{S}$ moieties in materials that contain large amounts of S (Kasrai et al., 1996) and may complement such studies.

\section{Effects of Land Use Changes on Sulfur Compounds in Size Separates}

In mature and undisturbed tropical forest ecosystems where the supply of S from the atmosphere is low, SOM plays a major role in $\mathrm{S}$ nutrition of plants by affecting the release of $S$ present as part of complex organic polymers. In these ecosystems, S cycling is essentially closed with minimal short-term losses or gains, as a balance exists between the input and output processes. The distribution of organic S across various oxidation states and functional forms thus reflects the history, present structure and functioning of the natural ecosystem. The equilibrium of SOM attained under undisturbed conditions and thereby the forms and dynamics of organic S, however, can be greatly affected by anthropogenic changes (McGill and Cole, 1981; McLaren and Swift, 1977; Solomon et al., 2001a), which often involve dramatic changes in vegetation cover, biomass production, and nutrient cycling in the ecosystem. Such changes also seem to be reflected in the S K-edge XANES spectroscopy of the humic substances extracted from these tropical soils. Following land use changes, the major shift in the composition of organic S compounds in the

Table 4. Relative abundance of $S$ at electronic oxidation states in clay $(<2 \mu \mathrm{m})$ and silt size $(2-20 \mu \mathrm{m})$ separates of tropical soils (Munesa, Ethiopia).

\begin{tabular}{|c|c|c|c|c|c|c|c|}
\hline \multirow[t]{3}{*}{ Land use } & \multicolumn{5}{|c|}{ Gaussian curve } & \multirow[t]{3}{*}{ R-S/O-S } & \multirow[t]{3}{*}{ I-S/O-S\$ } \\
\hline & G1 & G2 & G3 & G4 & G5 & & \\
\hline & $(0.33-0.47) \dagger$ & $(0.71-0.95)$ & (1.3-1.8) & (5.0) & (6.0) & & \\
\hline & \multicolumn{5}{|c|}{ Clay } & & \\
\hline Natural forest & 26.3 & 8.5 & 14.4 & 35.8 & 15.0 & 2.3 & 3.3 \\
\hline Cupresus plantation & 24.2 & 9.5 & 13.5 & 34.0 & 18.8 & 1.8 & 2.5 \\
\hline \multirow[t]{2}{*}{ Cultivation } & 21.6 & 5.3 & 9.3 & 30.3 & 33.5 & 0.80 & 1.2 \\
\hline & \multicolumn{5}{|c|}{$\underline{\text { Silt }}$} & & \\
\hline Natural forest & 14.5 & 2.2 & 5.4 & 37.4 & 40.5 & 0.41 & 1.1 \\
\hline Cupresus plantation & 17.1 & 3.2 & 4.2 & 29.2 & 46.3 & 0.44 & 0.72 \\
\hline Cultivation & 7.2 & 4.2 & 1.3 & 31.5 & 55.8 & 0.20 & 0.59 \\
\hline
\end{tabular}

$\dagger$ Electronic oxidation states.

+ R-S/O-S, ratios of most reduced S (sum of G1 and G2, which include sulfides, disulfides, thiols and thiophenes) to highly oxidized S (G5, representing sulfates).

$\S$ I-S/O-S, ratios of intermediate S (sum of G3 and G4, which include sulfoxides and sulfonates) to highly oxidized S (G5, representing sulfates). 
humic substances extracted from clay occurred in the most reduced S species (Fig. 4 and 5). The relative proportions of these S species (G1 and G2) decreased in the order: natural forests (38 and 35\%) > plantations (25 and $34 \%)>$ cultivated fields (17 and 30\%) at the Wushwush and Munesa sites, respectively. The proportions of intermediate $\mathrm{S}$ species in clay showed a relatively small but consistent decrease (from 46 and 50\% in natural forests to 41 and $48 \%$ in plantations and 39 and $40 \%$ in the cultivated fields for Wushwush and Munesa, respectively) at both sites. The ratio of R-S/ $\mathrm{O}-\mathrm{S}$ in the humic substances extracted from clay decreased in the order: natural forests $(2.2$ and 2.3$)>$ plantations $(0.76$ and 1.8$)>$ continuous cultivation $(0.40$ and 0.80 ), while the ratio of I-S/O-S dropped from 2.7 and 3.3 at the natural forests, to 1.2 and 2.5 in the plantations and to 0.89 and 1.2 in the cultivated fields at Wushwush and Munesa, respectively (Table 3 and 4). On the contrary, both the stacked spectra (Fig. 4 and 5) and the relative proportions of $S$ compounds (Table 3 and 4 ) indicate that the highly oxidized S increased considerably following deforestation and subsequent land use changes (from 17 and $15 \%$ in natural forests to 34 and $19 \%$ in plantations and 44 and $36 \%$ in continuously cultivated fields) at both sites.

The impact of land use changes on the different $\mathrm{S}$ compounds resolved by XANES spectroscopy was also visible in the humic substances extracted from silt size separates. Lower proportions of the most reduced and intermediate $\mathrm{S}$ species were generally found in size separates from the continuously cultivated fields and plantations than the corresponding natural forests (Table 3 and 4). Moreover, the R-S/O-S and I-S/O-S ratios in the humic substance extracts from the silt were generally lower than the ones from the natural forests. In contrast, the proportions of highly oxidized $\mathrm{S}$ forms increased in the order: natural forests $(40$ and $41 \%)<$ plantations (47 and $46 \%$ ) < cultivated fields (50 and 56\%) in humic substances extracted from the silt separates both at Wushwush and Munesa, respectively. The observed changes in the highly reduced and intermediate oxidation states following land use changes could be attributed to physical disruption of aggregates due to frequent exposure to rain drop impact, rapid wetting and drying, as well as through shearing by agricultural implements. The net effect of which is the loss of C-bonded S ( $\mathrm{S}$ in the most reduced and intermediate oxidation states) through increased aeration, stimulation of oxidation and exposure of the originally inaccessible organic $\mathrm{S}$ to the attack by soil microorganisms.

Even though a number of S speciation studies involving differential reduction techniques have observed both qualitative and quantitative changes in soil organic $\mathrm{S}$ due to cultivation, no consistent trends with regard to the interchange between different organic forms of $\mathrm{S}$ is yet apparent (Saggar et al., 1998; Solomon et al., 2001a). There is still conflicting evidence on the globally dominant labile form of organic S fraction, which can be taken as a major source of mineralizable S. For example, in organic $S$ mineralization studies on Canadian soils, Lowe (1964) considered C-bonded S to be of little value as a source of mineralizable S. In contrast, David et al. (1982) observed a decrease in C-bonded S and an increase in ester- $\mathrm{SO}_{4}-\mathrm{S}$ during an incubation experiment using forest soils. Freney et al. (1975), McLaren and Swift (1977), and Ghani et al. (1991) found that most of the inorganic $\mathrm{SO}_{4}^{2-}$ generated from soil originated from C-bonded $\mathrm{S}$ although there was a change in ester- $\mathrm{SO}_{4}-\mathrm{S}$ in a number of laboratory and field experiments conducted on both tropical and temperate soils. In our previous study on these soils, we have also demonstrated that C-bonded S contributed from 75 to $88 \%$ of the total S depletion, while only 11 to $26 \%$ of this loss derived from the ester- $\mathrm{SO}_{4}-\mathrm{S}$ due to land use changes, supporting the results of Freney et al. (1975), McLaren and Swift (1977), and Ghani et al. (1991). Based on the results of the present experiment, it is possible to suggest that there seems to be a link between the oxidation states, composition and bioavailability of the organic $\mathrm{S}$ species and level of soil degradation manifested by the loss of soil organic matter induced by land use changes. Our results indicate that organic $S$ in the most reduced and intermediate oxidation states plays the most important role in providing mineralizable organic S. Therefore, organic compounds in which $\mathrm{S}$ is directly linked to $\mathrm{C}\left(\mathrm{R}-\mathrm{SO}_{3}-\mathrm{H}\right.$ or $\left.\mathrm{R}-\mathrm{S}\right)$ can be considered as the most labile form of organic $\mathrm{S}$ in these subhumid tropical highland soils. These results further support the opinion that ester- $\mathrm{SO}_{4}-\mathrm{S}$ may have a more transitory nature and its mineralization is controlled by the supply of the end product. On the other hand, since $\mathrm{C}$-bonded $\mathrm{S}$ is mineralized as a result of $\mathrm{C}$ oxidation to provide energy for soil microorganisms, the increased aeration and thereby microbial activity associated with cultivation could result in an accelerated transformation of the C-bonded $\mathrm{S}$, which may passes through ester- $\mathrm{SO}_{4}-\mathrm{S}$ before release as inorganic $\mathrm{SO}_{4}-\mathrm{S}$. This mechanism would tend to maintain or increase the level of ester- $\mathrm{SO}_{4}-\mathrm{S}$ fraction observed in these soils, while continually diminishing C-bonded S (McGill and Cole, 1981 and Saggar et al., 1998; Solomon et al., 2001a). However, it is also possible that part of the organic $S$ in the most reduced and intermediate states may have been directly mineralized to inorganic $\mathrm{SO}_{4}^{2-}$ and either taken up by the plants or leached out of the system.

\section{CONCLUSIONS}

Sulfur K-edge XANES spectroscopy is a noninvasive technique that circumvents the limitations of chemical reduction methods, providing a characteristic fingerprint of the organic S compounds present in size separates and humic substance extracts of mineral soils. This study also highlighted the limitations of S K-edge XANES spectroscopy.

The white lines of the XANES spectra showed the presence of multiple oxidation states of organic $S$ in the humic substances and provided unequivocal evidence that $\mathrm{S}$ in intermediate oxidation states (especially sulfonates) are the dominant species of organic $S$ followed by highly oxidized and most reduced $\mathrm{S}$ compounds in organic matter associated with clay. In contrast, highly 
oxidized $\mathrm{S}$ (ester- $\mathrm{SO}_{4}-\mathrm{S}$ ) is dominant in organic matter associated with silt.

Sulfur XANES provided information about the link between $\mathrm{S}$ oxidation states, bioavailability of organic $\mathrm{S}$ moieties and the shifts that occur following land use changes. The results may indicate that organic $S$ in the most reduced and intermediate oxidation states plays a major role in providing mineralizable organic $\mathrm{S}$ in these tropical soils.

Based on our results, it is possible to conclude that S K-edge XANES spectroscopy offers a significant potential to evaluate the influence of anthropogenic changes on the nature and distribution of $\mathrm{S}$ and follow its dynamics in terrestrial ecosystems.

\section{ACKNOWLEDGMENTS}

We thank Prof. W. Zech, Dr. M. Tekalign, and Mr. F. Fritzsche for their support and for providing us access to the laboratory facilities at the University of Bayreuth, Germany. We thank Wushwush Tea Plantation and Munesa Forest Enterprise, Ethiopia for allowing us to carry out the research at their sites. The authors are grateful to Dr. W. Caliebe for invaluable assistance with the spectroscopic analyses. The $\mathrm{S}$ XANES experiment was performed at the beamline X-19A of the National Synchrotron Light Source (NSLS), Brookhaven National Laboratory (Project No. 4738). The National Synchrotron Light Source is supported by the U.S. Department of Energy under the contract No. DE-AC02-76CH00016.

\section{REFERENCES}

Anderson, D.W., S. Saggar, J.R. Bettany, and J.W.B. Stewart. 1981. Particle size fractions and their use in studies of soil organic matter: I. The nature and distribution of forms of carbon, nitrogen and sulfur. Soil Sci. Soc. Am. J. 45:767-772.

Avery, B.W., and C.L. Bascomb. 1974. Soil survey laboratory methods. p. 19-25. In Soil Survey Tech. Monogr., No. 6. Rothamsted Exp. Stn., Harpenden, UK.

Bettany, J.R., S. Saggar, and J.W.R. Stewart. 1980. Comparison of the amounts and forms of sulfur in soil organic matter fractions after 65 years of cultivation. Soil Sci. Soc. Am. J. 44:70-75.

Biederbeck, V.O. 1978. Soil organic sulfur and fertility. p. 273-310. In M. Schnitzer and S.M. Khan (ed.) Soil organic matter. Elsevier, Amsterdam, The Netherlands.

Blume, H.P., and U. Schwertmann. 1969. Genetic evaluation of profile distribution of aluminum, iron and manganese oxides. Soil Sci. Soc. Am. J. 33:438-444.

Brady, N.C., and R.R. Weil. 1999. The nature and properties of soils. Prentice Hall, NJ.

Carmo, A.M., B.A. Stankiewicz, M. Mastalerz, and L.M. Pratt. 1997. Factors controlling the abundance of organic sulfur in flash-pyrolyzates of upper Cretaceous kerogens from Sergipe Basin, Brazil. Org. Geochem. 26:587-603.

David, M.B., M.J. Mitchell, and J.P. Nakas. 1982. Organic and inorganic sulfur constituents of a forest soil and their relationship to microbial activity. Soil Sci. Soc. Am. J. 46:847-852.

Fitzgerald, J.W. 1976. Sulfate ester formation and hydrolysis: a potentially important yet often ignored aspect of the sulfur cycle of aerobic soils. Bacteriol. Rev. 40:698-721.

Freney, J.R., G.E. Melville, and C.H. Williams. 1975. Soil organic matter fractions as sources of plant-available sulfur. Soil Biol. Biochem. 22:1163-1165.

Fründ, R., and H.D. Lüdemann. 1989. The quantitative analysis of solution- and CPMAS-C-13 NMR spectra of humic material. Sci. Total Environ. 81/82:157-168.

Ghani, A., R.G. McLaren, and R.S. Swift. 1991. Sulfur mineralization in some New Zealand soils. Biol. Fertil. Soils 11:68-74.

Gressel, N., J.G. McColl, C.M. Preston, R.H. Newman, and R.F.
Powers. 1996. Linkages between phosphorus transformations and carbon decomposition in a forest soil. Biogeochemistry 33:97-123.

Houghton, C., and F.A. Rose. 1976. Liberation of sulfate from sulfate esters by soils. Appl. Environ. Microbiol. 31:969-976.

Huffman, G.P., N. Shah, F.E. Huggins, L.M. Stock, K. Chatterjee, J.J. Kilbane, II, M.M. Chou, and D.H. Buchanan. 1995. Sulfur speciation of desulfurized coals by XANES spectroscopy. Fuel 74:549-555.

Hundal, S.L., A.M. Carmo, and M.L. Thompson. 2000. Sulfur in biosolids-derived fluvic acid: Characterization by XANES spectroscopy and selective dissolution approaches. Environ. Sci. Technol. 34:5184-5188.

Hutchison, K.J., D. Hesterberg, and J.W. Chou. 2001. Stability of reduced organic sulfur in humic acid as affected by aeration and pH. Soil Sci. Soc. Am. J. 65:704-709.

Janzen, H.H., and B.H. Ellert. 1998. Sulfur dynamics in cultivated temperate agroecosystems. p. 11-43. In D.G. Maynard (ed.) Sulfur in the environment. Dekker, NY, USA.

Kasrai, M., J.R. Brown, G.M. Bancroft, Z. Yin, and K.H. Tan. 1996. Sulphur characterization in coal from X-ray absorption near edge spectroscopy. Int. J. Coal Geol. 32:107-135.

Kowalenko, C.G. 1993a. Extraction of available sulfur. p. 65-74. In M.R. Carter (ed.) Soil sampling and methods of analysis. Lewis Pub., FL.

Kowalenko, C.G. 1993b. Total and fractions of sulfur. p. 231-246. In M.R. Carter (ed.) Soil sampling and methods of analysis. Lewis Pub., Boca Raton, FL.

Lehmann, J., D. Günther, M.S. Mota, M. Almeida, W. Zech, and K. Kaiser. 2001. Inorganic and organic soil phosphorous and $S$ pools in an Amazonian multistrata agroforestry system. Agrofor. Syst. 53:113-124.

Lowe, L.E. 1964. An approach to the study of the sulfur status of soils and its application to selected Quebec soils. Can. J. Soil Sci. 44:176-179.

Lowe, L.E., and R.M. Bustin. 1989. Forms and hydrolytic behavior of Sulphur in humic acid and residue fractions of four peats from the Fraser lowland. Can. J. Soil Sci. 69:287-293.

Martínez, C.E., M.B. McBride, M.T. Kandianis, J.M. Duxbury, S.-J. Yoon, and W.F. Bleam. 2002. Zinc-sulfur and cadmium-sulfur association in metalliferous peats: Evidence from spectroscopy, distribution coefficients and phytoavailability. Environ. Sci. Technol. 36:3683-3689.

Mehra, O.P., and M.L. Jackson. 1960. Iron oxide removal from soils and clays by a dithionite-citrate system buffered with sodium bicarbonate. Clays Clay Miner. 7:317-327.

McGill, W.B., and C.V. Cole. 1981. Comparative aspects of cycling of organic C, N, S and P through soil organic matter. Geoderma 26:427-486.

McLaren, R.G., and R.S. Swift. 1977. Changes in soil organic sulfur fractions due to the long term cultivation of soils. J. Soil Sci. 28: 445-453.

Morra, M.J., S.E. Fendorf, and P.D. Brown. 1997. Speciation of S in humic and fulvic acids using X-ray absorbtion near-edge structure (XANES) spectroscopy. Geochim. Cosmochim. Acta 61:683-688.

Möller, A., K. Kaiser, W. Amelung, C. Niamskul, S. Udomsri, M. Puthawong, L. Haumaier, and W. Zech. 2000. Forms of organic C and $\mathrm{P}$ extracted from tropical soils as assessed by liquid-state ${ }^{13} \mathrm{C}$ and ${ }^{31}$ P-NMR spectroscopy. Aust. J. Soil Res. 38:1017-1035.

Möller, A., K. Kaiser, N. Kanchanakool, C. Anecksamphant, W. Jirasuktaveekul, A. Maglinao, C. Niamskul, and W. Zech. 2002. Sulfur forms in bulk soils and alkaline soil extracts of tropical mountain ecosystems in northern Thailand. Aust. J. Soil Res. 40:161-175.

Saggar, S., M.J. Hedley, and S. Phimsarn. 1998. Dynamics of Sulfur transformations in grazed pastures. p. 45-94. In D.G. Maynard (ed.) Sulfur in the environment. Marcel Dekker, New York.

Schnitzer, M., and S.U. Khan. 1972. Humic substances in the environment. Marcel Dekker Inc., New York.

Schnitzer, M. 1982. Organic matter characterization. p. 581-594. In A.L. Page et al. (ed.) Methods of soil analysis. Part 2. 2nd ed. Agron. Monogr. No. 9, ASA and SSSA, Madison, WI.

Soil Survey Staff. 1999. Soil taxonomy: A basic system of soil classification for making and interpreting soil surveys. 2nd ed. USDA, NRCS, Washington DC.

Solomon, D., J. Lehmann, and W. Zech. 2000. Land use effects on 
soil organic matter properties of chromic Luvisols in the semiarid tropics: Carbon, nitrogen, lignin and carbohydrates. Agric. Ecosyst. Environ. 78:203-213.

Solomon, D., J. Lehmann, M. Tekalign, F. Fritzsche, and W. Zech. 2001a. Sulfur fractions in particle-size separates of the subhumid Ethiopian highlands as influenced by land use changes. Geoderma 102:42-59.

Solomon, D., J. Lehmann, and W. Zech. 2001b. Land use effects on amino sugar signature of chromic Luvisols in the semi-arid part northern Tanzania. Biol. Fertil. Soils 33:33-40.

Solomon, D., F. Fritzsche, M.Tekalign, J. Lehmann, and W. Zech. 2002a. Soil organic matter composition in the sub-humid Ethiopian highlands as influenced by deforestation and agricultural management. Soil Sci. Soc. Am. J. 66:68-82.

Solomon, D., J. Lehmann, T. Mamo, F. Fritzsche, and W. Zech. 2002b. Phosphorus forms and dynamics as influenced by land use in the subhumid Ethiopian highlands. Geoderma 105:21-48.

Solomon, D., F. Fritzsche, J. Lehmann, M., Tekalign, and W. Zech. 2002c. Soil organic matter dynamics in the subhumid agroecosystems of the Ethiopian highlands: Evidence from natural ${ }^{13} \mathrm{C}$ abundance and particle size fractionation. Soil Sci. Soc. Am. J. 66: 969-978.

Stanko-Golden, K.M., and J.W. Fitzgerald. 1991. Sulfur transformation and pool size in tropical forest soils. Soil Biol. Biochem. 23:1053-1058.

StatSoft Inc. 1995. Statistica for Windows General convention and statistics. 2nd ed. StatSoft Inc., Tulsa, OK.

Stevenson, F.J. 1986. Cycles of Soil: Carbon, nitrogen, phosphorus, sulfur, micronutrients. John Wiley and Sons Inc., New York.

Sumann, M., W. Amelung, L. Haumaier, and W. Zech. 1998. Climatic effects on soil organic phosphorus in the North American Great
Plains identified by phosphorus-31 nuclear magnetic resonance. Soil Sci. Soc. Am. J. 62:1580-1586.

Szulczewski, M.D., P.A. Helmke, and W.F. Bleam. 2001. XANES spectroscopy studies of $\mathrm{Cr}(\mathrm{VI})$ reduction by thiols in organic compounds and humic substances. Environ. Sci. Technol. 35:1134-1141.

Tabatabai, M.A. 1982. Sulfur. p. 501-538. In A.L. Page et al. (ed.) Methods of soil analysis. Part 2. 2nd ed. Agron. Monogr. No. 9 , ASA and SSSA, Madison, WI.

Vairavamurthy, A., B. Manowitz, G.W. Luther, III, and Y. Jeon. 1993. Oxidation state of sulfur in thiosulfate and implications for anaerobic energy metabolism. Geochem. Cosmochim. Acta. 57: $1619-1623$.

Vairavamurthy, A., W. Zhou, T. Eglinton, and B. Manowitz. 1994. Sulfonates: A novel class of organic sulfur compounds in marine sediments. Geochem. Cosmochim. Acta. 58:4681-4687.

Van Loon, W.M.G.M., J.J. Boon, and B. Groot. 1993. Quantitative analysis of sulfonic acid groups in macromolecular lignosulfonic acids and aquatic humic substances by temperature-resolved pyrolysis-mass spectrometry. Environ. Sci. Technol. 27:2387-2396.

Waldo, G.S., R.M.K. Carlson, J.M. Moldowan, K.E. Petters, and J.E. Penner-Hahn. 1991a. Sulfur speciation in heavy petroleum: Information from x-ray absorption near edge structure. Geochemi. Cosmochim. Acta. 55:801-814.

Waldo, G.S., O.C. Mullins, J.E. Penner-Hahn, and S.E. Cramer. 1991b. Determination of the chemical environment of sulfur in petroleum asphaltenes by x-ray absorption spectroscopy. Fuel 70:549-559.

Wilding, L.G. 1985. Spatial variability: Its documentation, accommodation and implication to soil survey. p. 166-187. In D.R. Nielsen and J. Bouma (ed.) Soil spatial variability. PUDOC, Wageningen, The Netherlands.

Xia, K., F. Weesner, W.F. Bleam, P.R. Bloom, U.L. Skyllberg, and P.A. Helmke. 1998. XANES studies of oxidation states in aquati and soil humic substances. Soil Sci. Soc. Am. J. 62:1240-1246. 